\title{
PENDIDIKAN KESEHATAN MELALUI ANIMASI DUA DIMENSI TERHADAP PENGETAHUAN DAN SIKAP REMAJA TENTANG HIV/AIDS
}

\section{Health Education Through Two Dimensional Animations on Teenages Knowledge and Attitudes About HIV/AIDS}

\author{
Ageng Abdi Putra ${ }^{1}$, Suhartiningsih ${ }^{2}$, Haerunnisa $^{3}$ \\ ${ }^{1}$ Departemen Keperawatan Anak, Sekolah Tinggi Ilmu Kesehatan (STIKES) Mataram. \\ ${ }^{2}$ Departemen Keperawatan Gawat Darurat, Sekolah Tinggi Ilmu Kesehatan (STIKES) Mataram. \\ ${ }^{3}$ Mahasiswa Program Studi S1 Keperawatan, Sekolah Tinggi Ilmu Kesehatan (STIKES) Mataram. \\ Korespondensi : agenk.putra@yahoo.com
}

\begin{abstract}
ABSTRAK
Insiden HIV di Indonesia mencapai 0,19 per 1000 penduduk. Jumlah orang dengan HIV di Lombok Barat sebanyak 126 jiwa serta orang dengan AIDS sebanyak 114 jiwa. Secara kumulatif jumlah orang dengan HIV/AIDS di wilayah Batulayar sebanyak 313 jiwa. Remaja termasuk kelompok usia yang rentan dengan perilaku beresiko terkena HIV/AIDS karena pergaulan dan lingkungan. Penelitian ini bertujuan untuk mengetahui pengaruh pendidikan kesehatan melalui animasi dua dimensi terhadap pengetahuan dan sikap remaja tentang HIV/AIDS di SMAN 1 Batulayar. Desain penelitian yang digunakan dalam penelitian ini adalah pre experimental dengan rancangan penelitian one grup pretest-posttest. Teknik pengambilan sampel menggunakan nonprobability sampling dengan total sampling. Analisa data yang digunakan adalah wilcoxon signed rank test dengan taraf signifikan 0,05. Berdasarkan hasil uji wilcoxon signed ranks, didapatkan nilai $p$ sebesar 0,000. Dapat disimpulkan, ada pengaruh pendidikan kesehatan melalui animasi dua dimensi terhadap pengetahuan dan sikap remaja yang ditunjukkan adanya peningkatan pengetahuan yang signifikan pada remaja. Pendidikan kesehatan melalui animasi dua dimensi sangat bagus digunakan dalam proses belajar mengajar karena akan lebih mudah dipahami dan dimengerti untuk meningkatkan pengetahuan dan sikap remaja.
\end{abstract}

Kata kunci: pendidikan kesehatan, pengetahuan, sikap, HIV/AIDS

\section{ABSTRACT}

The incidence of HIV in Indonesia reaches 0.19 per 1000 population. The number of people living with HIV in West Lombok is 126 people and 114 people living with AIDS. The cumulative number of people living with HIVIAIDS in the Batulayar region is 313 people. Adolescents are included in the vulnerable age group with behaviors that are at risk of contracting HIVIAIDS due to relationships and environment. This study aims to determine the effect of health education through two-dimensional animation on adolescent knowledge and attitudes about HIV/AIDS at SMAN 1 Batulayar. The research design used in this study was pre-experimental with a one-group pretest-posttest research design. The sampling technique used nonprobability sampling with total sampling. The data analysis used was the wilcoxon signed rank test with a significant level of 0.05. Based on the results of the wilcoxon signed ranks test, the $p$ value was 0,000. It can be concluded, there is an effect of health education through two-dimensional animation on knowledge and attitudes of adolescents which is indicated by a significant increase in knowledge in adolescents. Health education through twodimensional animation is very good to use in the teaching and learning process because it will be easier to understand and understand to increase the knowledge and attitudes of adolescents.

Keyword : health education, knowledge, attitude, HIV/AIDS 
Ageng Abdi Putra, dkk: Pendidikan Kesehatan Melalui Animasi Dua Dimensi terhadap Pengetahuan dan Sikap Remaja Tentang HIV/AIDS

PENDAHULUAN

Human Immunodeficiency Virus (HIV) dan Acquired Immune Deficiency Syndrome (AIDS) masih menjadi permasalahan kesehatan masyarakat secara global. Walaupun insiden HIV telah menurun dari 0,40 per 1000 populasi yang tidak terinfeksi menjadi 0,26 per 1000 populasi yang tidak terinfeksi di tahun 2016 (UNAIDS, 2017), namun kecenderungannya masih memprihatinkan. Hingga akhir tahun 2017, World Health Organization (WHO) melaporkan terdapat sekitar 36,9 juta orang dengan HIV/AIDS (ODHA), 940.000 kematian karena HIV, dan 1,8 juta orang terinfeksi baru HIV atau sekitar 5000 infeksi baru per harinya (WHO, 2018).

Berdasarkan laporan rumah sakit/puskesmas dan laporan rutin AIDS kabupaten/kota tahun 2018, jumlah kasus HIV/AIDS yang ditemukan mengalami peningkatan dibandingkan tahun 2017. Jumlah kasus yang ditemukan tahun 2017 adalah 98 kasus HIV, dan 111 kasus AIDS sedangkan tahun 2018 adalah 155 kasus HIV dan 101 kasus baru AIDS. Jumlah kematian karena AIDS di Provinsi NTB tahun 2017 sebanyak 22 kasus dan tahun 2018 terjadi 24 kematian akibat AIDS. (Riskesdas, 2018).

Salah satu cara yang dapat dilakukan untuk menekan penularan HIV/AIDS adalah dengan melakukan pendidikan kesehatan pada masyarakat, khususnya pada kelompok remaja. Selama ini pendidikan kesehatan pada remaja tentang dampak (Bahaya) HIV/AIDS dan pencegahannya masih dirasakan kurang optimal. Media yang dapat digunakan dalam pendidikan kesehatan dapat bermacam-macam antara lain yaitu, media visual, media audio, media audio visual dan multimedia (Sovia, 2019).

Berdasarkan hasil studi pendahuluan yang dilakukan peneliti di SMA Negeri 1 Batulayar, pada tanggal 25 November 2019 dengan guru Bimbingan Konseling mengatakan bahwa belum pernah ada penyuluhan maupun pendidikan kesehatan tentang HIV/AIDS pada remaja, dan jarang sekali ada yang memberi penyuluhan atau pendidikan kesehatan di lingkungan sekolahnya. Hasil wawancara kepada 15 siswa dari sekolah SMA Negeri 1 BATULAYAR rata-rata dari 15 siswa mengatakan kalau mereka hanya mengetahui tentang apa itu HIV/AIDS saja dan belum mengetahui secara pasti penyebab lain dari HIV/AIDS. sekolah ini termasuk ke dalam sekolah yang berada di daerah pariwisata karena letak sekolah SMA Negeri 1 Batulayar berada di Jalan Raya Senggigi, Meninting, Kabupaten Lombok Barat.

Peningkatan HIV/AIDS setiap tahun akan berdampak pada peningkatan angka kesakitan dan kematian, serta berdampak pada masalah psikologi dan social. Oleh sebab itu, di butuhkan upaya promotif dan preventif untuk memperkenalkan kepada masyarakat luar, khusunya pada kelompok usia remaja, tentang bahaya, pencegahan, dan penangguulangan HIV/AIDS (Sovia, S, 2019). Melihat besarnya pengaruh negatif yang dapat terjadi pada remaja maka peneliti tertarik untuk meneliti tentang Pengaruh Pendidikan Kesehatan Melalui Animasi Dua Dimensi Terhadap Pengetahuan Dan Sikap Remaja Tentang HIV/AIDS di SMAN 1 Batulayar.

\section{TUJUAN PENELITIAN}

Penelitian ini bertujuan untuk mengetahui pengaruh pendidikan kesehatan melalui animasi dua dimensi terhadap pengetahuan dan sikap remaja tentang HIV/AIDS di SMAN1 Batulayar..

\section{METODE PENELITIAN}

Desain

Desain yang digunakan pada penelitian ini merupakan jenis pre experimental dengan rancangan penelitian one grup pretest-posttest design.

\section{Populasi dan Sampel}

Populasi terjangkau pada penelitian ini adalah semua anak remaja kelas XII di SMAN 1 Batulayar. Sampel ditentukan berdasarkan teknik nonprobability sampling dengan total sampling, jumlah sampel sebanyak 40 responden. 
Ageng Abdi Putra, dkk: Pendidikan Kesehatan Melalui Animasi Dua Dimensi terhadap Pengetahuan dan Sikap Remaja Tentang HIV/AIDS

Tempat dan Waktu Penelitian

Penelitian ini bertempat di SMAN 1

Batulayar. dan pengumpulan data dilaksanakan selama 1 minggu.

\section{Intervensi}

Perlakuan yang diberikan adalah berupa pendidikan kesehatan dengan memanfaatkan animasi dua dimensi yang diberikan sekali dalam seminggu.

\section{Instrumen dan Prosedur Pengukuran}

Instrumen yang digunakan dalam penelitian ini adalah kuesioner pengetahuan dan sikap tentang HIV/AIDS dari Mukti (2018). Pengetahuan diukur menggunakan 2 alternatif jawaban benar nilai sama dengan 1 dan salah sama dengan 0 . Nilai atas jawaban dijumlah untuk memperoleh skor, pertanyaan berjumlah 36 pernyataan terkait dengan pengetahuan siswa tentang HIV/AIDS total skor tertinggi adalah 36. Pengukuran sikap menggunakan skala linkert. Jumlah pertanyaan 20 item, masingmasing pertanyaan terdapat empat pilihan jawaban yaitu sangat setuju (ST), setuju (S), tidak setuju (TS), dan sangat tidak setuju (STS). Pertanyaan positif (Favorable) nomor 1,18,7,11,12 dan 13. Bila di jawab $\mathrm{SS}=4, \quad \mathrm{~S}=3, \quad \mathrm{TS}=2, \quad \mathrm{STS}=1 \quad$ pertanyaan negative. Total skor tertinggi adalah 19 .

\section{Analisa Data}

Analisa data dalam penelitian ini menggunakan analisa bivariat dengan menggunakan uji wilcoxon signed rank.

\section{HASIL PENELITIAN}

Hasil penelitian sebagai berikut:

\section{Tabel 1}

Tingkat Pengetahuan Remaja Sebelum dan Sesudah Diberikan Pendidikan Kesehatan Melalui Animasi Dua Dimensi $(\mathrm{n}=40)$

\begin{tabular}{ccccc}
\hline \multirow{2}{*}{ Pengetahuan } & \multicolumn{2}{c}{ Pre-test } & \multicolumn{2}{c}{ Post-test } \\
\cline { 2 - 5 } & f & \% & f & $\%$ \\
\hline Baik & 3 & 7.5 & 36 & 90 \\
Cukup & 8 & 20 & 4 & 10 \\
Kurang & 29 & 72.5 & 0 & 0 \\
\hline
\end{tabular}

Tabel 1 menunjukkan bahwa pengetahuan responden sebelum di berikan intervensi sebagian besar responden dengan Pengetahuan kurang berjumlah 29 responden $(72,5 \%)$. Berdasarkan tabel di atas dapat di lihat bahwa pengetahuan responden sesudah di berikan intervensi, sebagian besar responden dengan pengetahuan baik berjumlah 36 responden $(90 \%)$.

Tabel 2

Sikap Remaja Sebelum dan Sesudah Diberikan Pendidikan Kesehatan Melalui Animasi Dua Dimensi $(\mathrm{n}=40)$

\begin{tabular}{ccccc}
\hline \multirow{2}{*}{ Sikap } & \multicolumn{2}{c}{ Pre-test } & \multicolumn{2}{c}{ Post-test } \\
\cline { 2 - 5 } & f & \% & f & \% \\
\hline Positif & 11 & 27.5 & 35 & 87.5 \\
Negatif & 29 & 72.5 & 5 & 12.5 \\
\hline
\end{tabular}

Tabel 2 menunjukkan bahwa sikap responden sebelum di berikan intervensi, sebgaian besar responden dengan sikap negative berjumlah 29 responden $(72,5 \%)$. Berdasarkan tabel di atas dapat di lihat bahwa sikap responden sesudah di berikan intervensi, sebgaian besar responden dengan sikap positif berjumlah 35 responden $(87.5 \%)$

Tabel 3

Pengaruh Pendidikan Kesehatan Melalui Animasi Dua Dimensi terhadap Pengetahuan dan Sikap Remaja tentang HIV/AIDS $(n=40)$

\begin{tabular}{cccc}
\hline Variabel & Mean & SD & p-value \\
\hline Pengetahuan & & & \\
Sebelum & 19.22 & 3.025 & .000 \\
Setelah & 31.22 & 2.694 & \\
\hline Sikap & & & \\
Sebelum & 9.12 & 1.727 & .000 \\
Setelah & 15.68 & 2.990 & \\
\hline
\end{tabular}

Tabel 3 menunjukkan bahwa hasil uji statistik di dapatkan nilai $\mathrm{p}$ sebesar 0,000 artinya $\mathrm{p}$ lebih kecil dari 0,05 , dan nilai ratarata nilai pengetahuan setelah diberikan intervensi 31,22 dengan standard deviasi 2.694. selain itu, hasil pengukuran sikap yang dilakukan setelah diberikan intervensi pendidikan kesehatan melalui gambar dua dimensi menunjukkan nilai $\mathrm{p}$ sebesar 0,000 dengan nilai rata-rata sikap 15,68 dengan standar deviasi 2.990. Dapat disimpulkan bahwa terdapat pengaruh pendidikan kesehatan melalui animasi dua dimensi 
terhadap pengetahuan dan sikap remaja tentang HIV/AIDS di SMAN 1 Batulayar.

\section{PEMBAHASAN}

Temuan penelitian ini menunjukkan bahwa tingkat pengetahuan tentang HIV/AIDS pada remaja sebelum di berikan pendidikan kesehatan melalui animasi dua dimensi dalam kategori kurang sebanyak 29 responden $(72,5)$, usia yang paling banyak usia remaja 18 tahun. Setelah di berikan pendidikan kesehatan melalui animasi dua dimensi terjadi peningkatan pengetahuan yang signifikan, pengetahuan baik sebanyak 36 orang $(90 \%)$ dan pengetahuan cukup sebanyak 4 orang $(10 \%)$, dan tidak ada remaja yang berpengetahuan kurang. Hal tersebut menjadi indikator bahwa saat menonton animasi dua dimensi melalui daring remaja memperhatikan dengan baik.

Hasil uji statistik di peroleh bahwa ada pengaruh pendidikan kesehatan melalui animasi dua dimensi terhadap tingkat pengetahuan remaja tentang HIV/AIDS di SMAN 1 Batulayar. Penelitian ini sejalan dengan penelitian yang di lakukan oleh Saadong, Djuhadiah, et al. (2018) dengan hasil penelitian menunjukkan bahwa ada pengaruh pendidikan kesehatan terhadap pengetahuan remaja tentang pencegahan HIV/AIDS. Penelitian Harmawati (2018) menunjukkan bahwa ada pengaruh pendidikan kesehatan terhadap tingkat pengetahuan pelajar SMA tentang HIV/AIDS. Penelitian ini juga sesuai dengan pernyataan Sovia (2019), bahwa penggunaan media animasi lebih efektif daripada media powerpoint dalam pemberian informasi tentang penyakit HIV/AIDS pada remaja. Penelitian yang dilakukan oleh Aspiawati (2018) juga menunjukkan ada pengaruh yang signifikan antara media video animasi terhadap pengetahuan remaja tentang HIV/AIDS.

Temuan sikap remaja menunjukkan bahwa sikap sebelum di berikan intervensi, sebgaian besar dengan sikap negative berjumlah 29 responden $(72,5 \%)$, dan sesudah di berikan intervensi, sebgaian besar responden dengan sikap positif berjumlah 35 responden $(87.5 \%)$. Berdasarkan hasil uji statistik diperoleh bahwa ada pengaruh pendidikan kesehatan melalui animasi dua dimensi terhadap sikap remaja tentang HIV/AIDS di SMAN 1 Batulayar.

Peningkatan pada sikap remaja dari hasil temuan ini dapat juga disebabkan oleh faktor yang membentuk sikap seperti yang di kemukakan oleh (Azwar, 2016) bahwaa faktor-faktor yang membentuk dan mempengaruhi sikap manusia yaitu pengalaman pribadi, untuk dapat menjadi dasar pembentukan sikap pengalaman peibadi harus meninggalkan kesan yang kuat supaya membentuk suatu dasar seseorang bersikap dan belajar; pengaruh orang lain, sikap seseorang sangat mempengaruhi; pengaruh kebudayaan, kebudayaan memegang peran penting dalam terbentuknya sikap penecgehan HIV/AIDS karena kebudayaan dimana responden itu tinggal dan di besarkan mempunyai pengaruh besar terhadap sikap maupun perilaku responden tersebut; media massa; lembaga, pendidikan dan lemabaga agama karena lingkup dari responden sendiri adah pengajar/guru di sekolah dan peraturanperaturan yang di bentuk dan berlaku di lingkungan sekolah tersebut.

Penelitian ini sejalan dengan penelitian yang dilakukan Muliana (2014) dimana ditemukan ada pengaruh pendidikan kesehatan tentang pencegahan HIV/AIDS terhadap pengetahuan dan sikap remaja. Liana (2015) menyatakan bahwa pendidikan kesehatan dengan audio-visual berpengaruh signifikan terhadap pengetahuan dan sikap remaja terhadap HIV/AIDS. Sikap merupakan reaksi atau respon yang masih tertutup dari seseorang terhadap suatu stimulus atau objek. Sikap terdiri atas beberapa tingkatan, yaitu menerima (receiving), merespon (responding), menghargai (valuing), dan bertanggung jawab (responsible). Tahapan pembentukan sikap akan mengubah sikap seseorang dari negatif menjadi positif. Oleh karena itu pembentukan sikap positif tersebut memerlukan waktu yang cukup lama dengan intensitas pemberian pendidikan kesehatan yang sering (Notoadmojo, 2012). Pendidikan kesehatan menggunakan animasi dua dimensi sangat efektif dalam 
memberikan informasi kepada siswa-siswi SMAN 1 Batulayar. Karena proses yang menyenangkan serta tidak hanya mendengarkan ceramah namun menjadi point penting tersendiri, sehingga siswa menjadi lebih mudah untuk menerima informasi. Hal ini dapat dibuktikan pada hasil pre-test dan post-test menunjukkan peningkatan pengetahuan dan sikap remaja dalam aspek HIV/AIDS.

Sovia (2019) menyatakan penggunaan media animasi lebih efektif daripada media powerpoint dalam pemberian informasi tentang penyakit HIV/AIDS pada remaja. Mukti (2018) juga menyatakan bahwa Pendidikan kesehatan meningkatkan pengetahuan dan sikap remaja secara signifikan.

\section{KESIMPULAN}

Implikasi

Temuan pada penelitian ini Temuan pada penelitian ini menunjukkan adanya pengaruh pendidikan kesehatan melalui animasi dua dimensi terhadap pengetahuan dan sikap remaja di SMAN 1 Batulayar. Informasi yang baik dan akurat tentang HIV/AIDS atau bahaya HIV/AIDS dapat meningkatkan pengetahuan dan sikap kewaspadaan terhadap penularan HIV/AIDS. Oleh karena itu peneliti mengharapkan agar informasi tentang HIV/AIDS dapat ditingkatkan lagi melaui program layanan kesehatan yang sudah berjalan maupun kesadaran seara individu khususnya perawat untuk menyampaikan informasi dengan baik guna mencegah terjadinya penluran HIV/AIDS khususnya pada remaja.

\section{Keterbatasan}

Dalam penelitian ini ada beberapa keterbatasan yang di alami oleh peneliti selama penelitian berlangsung diantaranya adalah peneliti terkendala dalam menetapkan kontrak waktu untuk melakukan penelitian dikarenakan sedang terjadi wabah virus covid 19; peneliti terkendala dalam menyebarkan kuesioner dan video karena melalui google form dan aplikasi whatsaap; peneliti tidak dapat mengontrol secara langsung responden saat mengisi kuesioner pre-test \& post-test dikarenakan penelitian secara daring.

\section{DAFTAR PUSTAKA}

Aspiawati, A. (2018). Pengaruh Pendidikan Kesehatan Berbasis Media Video Animasi Terhadap Pengetahuan Remaja tentang HIV/AIDS (Doctoral dissertation, Universitas Islam Negeri Alauddin Makassar).

Azwar,Saifuddin.2016. sikap dan perilaku. Pustaka Pealajar.Yogyakarta

Harmawati, H., Sari, D. A., \& Verini, D. (2018). Pengaruh Pendidikan Kesehatan Terhadap Tingkat Pengetahuan Pelajar SMA Tentang HIV/AIDS. Jurnal Endurance, 3(3), 588-595.

Liana, L., \& Asnindari, L. N. (2015). Pengaruh Pendidikan Kesehatan dengan Audiovisual Tentang HIV/AIDS Terhadap Pengetahuan dan Sikap Remaja Kelas X SMK N 1 Bantul (Doctoral dissertation,STIKES'Aisyiyah Yogyakarta).

Mukti, G. A., Tyastuti, S., \& Hernayanti, M. R. (2018). Pengaruh Peer Education Terhadap Pengetahuan dan Sikap Remaja Tentang HIV/AIDS di SMA N 1 Kretek Bantul Tahun 2018 (Doctoral dissertation, Poltekkes Kemenkes Yogyakarta).

Muliana, M. (2014). Pengaruh pendidikan kesehatan terhadap tingkat pengetahuan dan sikap remaja sma $\mathrm{x}$ dalam upaya pencegahan hiv/aids di kabupaten karanganyar (Doctoral dissertation, Universitas Muhammadiyah Surakarta).

Notoatmojo, S. (2012). Pendidikan Kesehatan \& Perilaku Kesehatan. Jakarta :Rineka Cipta

Riskesdas. (2018). Badan Penelitian dan Pengembangan Kesehatan Kementerian RI 2018.

Saadong, Djuhadiah, et al. (2018) "Pengaruh Pendidikan Kesehatan Terhadap Pengetahuan Remaja Tentang Pencegahan Hiv/aids Di Smk 
Ageng Abdi Putra, dkk: Pendidikan Kesehatan Melalui Animasi Dua Dimensi terhadap Pengetahuan dan Sikap Remaja Tentang HIV/AIDS

Komputer Mutiara Ilmu Makassarthe Effect of Health Education on Youth Knowledge About Prevention of Hiv/aids in Computer Vocational School, Mutiara Ilmu Makassar." Media Kesehatan Politeknik Kesehatan Makassar, vol. 13, no. 2, 2018, pp. 5358.

Sovia, S. (2019). Efektifitas Penggunaan Media Animasi Untuk Meningkatkan Pengetahuan Tentang HIV/AIDS. Jambura Journal of Health Sciences and Research, 1(2), 37-46.

UNAIDS. Global Report: UNAIDS report on the global AIDS epidemic 2017. Geneva: Joint United Nations Programme on HIV/AIDS; 2017.

WHO. Global health observatory data: HIV/AIDS. 